\title{
An infant with hypercalcemia: Questions
}

\author{
Stefano Guarino • Pierluigi Marzuillo • Andrea Apicella • \\ Luigi Annicchiarico Petruzzelli • Angela La Manna
}

Received: 19 August 2013 /Revised: 20 August 2013 / Accepted: 6 September 2013 / Published online: 19 October 2013

(C) IPNA 2013

\section{Keywords Hypercalcemia}

A 6-month-old male infant born by normal vaginal delivery (birth weight $3.150 \mathrm{~kg}$, length $49 \mathrm{~cm}$ ) and affected by hypospadias underwent renal ultrasound scan (Fig. 1). Expert advice was required after an "uncertain renal US report".

The patient suffered decreased appetite, vomiting, constipation, polyuria and polydipsia during the previous 2 months. At our appointment, we found hypotonia, irritability, failure to thrive, anterior fontanelle $1.5 \times 1 \mathrm{~cm}$, and moderate dehydration. His mother reported that the infant was taking no drugs except prophylaxis with vitamin D (400 IU/day).

Serum chemistry was as follows: calcium $18.67 \mathrm{mg} / \mathrm{dl}$ (normal range, $8.4-10.2 \mathrm{mg} / \mathrm{dl}$ ), urea $65 \mathrm{mg} / \mathrm{dl}(10-50 \mathrm{mg} /$ dl), creatinine $0.45 \mathrm{mg} / \mathrm{dl}$, phosphorus $5.7 \mathrm{mg} / \mathrm{dl}, \mathrm{Ca} \times \mathrm{P}$ $106 \mathrm{mg}$ (normal value $<55 \mathrm{mg}$ ), venous $\mathrm{pH}$ 7.38. $\mathrm{Na}, \mathrm{K}, \mathrm{Cl}$, $\mathrm{Mg}, \mathrm{HCO}_{3}, \mathrm{ABE}$, glycemia, AST, ALT, $\gamma \mathrm{GT}$, bilirubin, alkaline phosphatase and complete blood count were within normal limits. Urinary electrolyte concentrations: calcium/ creatinine ratio $1.27 \mathrm{mg} / \mathrm{mg}$, uric acid/creatinine $0.45 \mathrm{mg} / \mathrm{dl}$ of glomerulor filtration rate, beta2 microglobulin $0.4 \mathrm{mg} / \mathrm{l}$ (nv: $<0.3 \mathrm{mg} / \mathrm{l})$.

ECG, cardiologic and oculistic examination, and blood pressure monitoring were normal.

We started hyperhydration $(\mathrm{NaCl} \quad 0.9 \% 7 \mathrm{ml} / \mathrm{kg} / \mathrm{h})$ to reduce calcemia. After $12 \mathrm{~h}$, the blood calcium was $15.2 \mathrm{mg} /$ dl. Therefore we added furosemide $(1 \mathrm{mg} / \mathrm{kg}$ intravenously twice a day) and methylprednisolone (1 mg/ $\mathrm{kg}$ once a day). After 4 days of therapy, the blood calcium was $13.8 \mathrm{mg} / \mathrm{dl}$ and urinary calcium/creatinine ratio was $2.61 \mathrm{mg} / \mathrm{mg}$.

The clinical conditions of the patient improved after 4 days (no vomiting, increased appetite).

The serum level of calcium did not decrease after 6 days of therapy with furosemide and methylprednisolone, remaining at $13.8 \mathrm{mg} / \mathrm{dl}$.

\section{Questions:}

1) What do you think about the US appearance?

2) What additional investigations are necessary for diagnosis and what was the cause of hypercalcemia?

3) What is the next step of therapy for hypercalcemia?

Fig. 1 Renal ultrasound of an infant with hypercalcemia
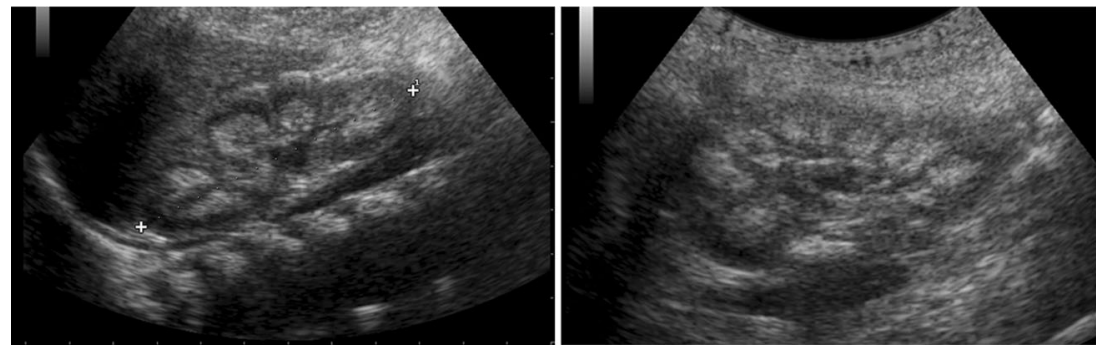

The answers to these questions can be found at http://dx.doi.org/10.1007/ s00467-013-2639-9.

S. Guarino $(\bowtie) \cdot$ P. Marzuillo $\cdot$ A. Apicella

L. Annicchiarico Petruzzelli - A. La Manna

Department of women and children and general and specialized

surgery, Seconda Università degli Studi di Napoli, Via L.De Crecchio

2, 80138 Naples, Italy

e-mail: stefano.grn@hotmail.com 